Original Research Article

\title{
Evaluation and comparison of nephroprotective effect of Hemidesmus indicus Linn. and Withania somnifera Linn. on gentamicin induced nephrotoxicity in Albino rats
}

\author{
Mugdha Rajeeva Padhye, Sangita Devrao Jogdand*, Jagruti Bhattacharjee
}

Department of Pharmacology, Jawaharlal Nehru Medical College, Sawangi (Meghe), Wardha, Maharashtra, India

Received: 08 January 2018 Revised: 09 February 2018 Accepted: 27 February 2018

\section{*Correspondence to:}

Dr. Sangita Devrao Jogdand, Email: drsangitaraj@gmail.com

Copyright: (C) the author(s), publisher and licensee Medip Academy. This is an openaccess article distributed under the terms of the Creative Commons Attribution NonCommercial License, which permits unrestricted noncommercial use, distribution, and reproduction in any medium, provided the original work is properly cited.

\begin{abstract}
Background: Nephrotoxicity is a known deleterious effect of Aminoglycoside antibiotics. This class of antibiotics is used very frequently. It is well known that Gentamicin causes renal tubular necrosis in the proximal tubular cells. Phytochemicals are being studied extensively and have proved to be of benefit in various diseases. The use of phytochemicals would minimize the adverse effects encountered with these antibiotics. Comparison between various phytochemicals would help in optimizing dosage and duration of treatment. In the present study we studied and compared the nephroprotective effect of Hemidesmus Indicus Linn. and Withania Somnifera Linn. on Gentamicin induced nephrotoxicity in Albino rats.

Methods: Wistar albino rats weighing 180-250Gms were utilized for the present study. The root extract of these Hemidesmus Indicus Linn. and Withania Somnifera Linn. was administered orally to rats for 10 days concurrently with Gentamicin. Nephrotoxicty was assessed following a single dose injection of Gentamicin. Nephroprotective effect was assessed after 10 days of administering Hemidesmus Indicus Linn. and Withania Somnifera Linn. Renal function was assessed using Blood Urea, Serum Creatinie, SOD (Superoxide Dismutase) and MDA (Malondialdehyde) as parameters.

Results: Statistically significant improvement in renal function $(p<0.05)$ was seen after administration of Hemidesmus Indicus and Withania Somnifera in Gentamicin treated rats. There was significant reduction in blood urea, serum creatinine and MDA levels with an increase in SOD levels.

Conclusions: Withania Somnifera and Hemidesmus Indicus had nephroprotective effect. However, Withania Somnifera was found to be more nphroprotective than Hemidesmus Indicus.
\end{abstract}

Keywords: Gentamicin, Nephrotoxicity, Phytochemicals

\section{INTRODUCTION}

Aminoglycoside is a medicinal and bacteriologic category of gram-negative antibacterial therapeutic agents that inhibit protein synthesis and contain as a portion of the molecule an amino-modified glycoside (sugar). ${ }^{1}$

They are useful primarily in infections involving aerobic, Gram-negative bacteria, such as Pseudomonas, Acinetobacter and Enterobacter. In addition, some
Mycobacteria, including the bacteria that cause tuberculosis, are susceptible to aminoglycosides. Streptomycin was the first effective drug in the treatment of tuberculosis, though the role of aminoglycosides such as streptomycin and amikacin has been eclipsed (because of their toxicity and inconvenient route of administration) except for multiple-drug-resistant strains. The most frequent use of aminoglycosides is empiric therapy for serious infections such as septicemia, complicated intraabdominal infections, complicated urinary tract 
infections, and nosocomial respiratory tract infections. Usually, once cultures of the causal organism are grown and their susceptibilities tested, aminoglycosides are discontinued in favor of less toxic antibiotics. ${ }^{2}$

Gentamicin is a broad-spectrum antibiotic belonging to aminoglycoside group. It is very effective against gramnegative and some gram positive bacterial infections.

Gentamicin is well recognized, to produce renal tubular necrosis mainly in the proximal tubule. This drug causes generation of reactive oxygen species (ROS), which induces cell injury and necrosis via lipid peroxidation.

The kidney is an essential excretory organ of our body. It plays a vital role in homeostasis by excreting the metabolic waste products and excess necessary substances. It is the prime target of several drugs, toxic xenobiotics or chemicals due to high rate of blood flow $(20 \%-25 \%$ of cardiac output) and presence of cellular transport systems that causes accumulation of these compounds within the nephron epithelial cells. Metabolites of the drugs that are excreted from kidney may also cause cellular damage leading to kidney dysfunction. Several xenobiotic substances like aminoglycosides, cephalosporins, anticancer drugs (cisplatin), amphotericin B, analgesics etc exert their toxic effects by one or more common pathogenic mechanism that can produce nephrotoxicity.

Nephrotoxicity is defined as renal dysfunction occurring as a direct result of exposure to external agents such as drugs and environmental chemicals. ${ }^{5}$

Nephrotoxicity and ototoxicity are the major limitations of Aminoglycoside use in clinical practice. Complications caused by aminoglycoside toxicity are one of the most common reasons for prolonging hospital stays. ${ }^{6}$ Data shows that up to $30 \%$ of patients treated with GM for more than 7 days show signs of nephrotoxicity. ${ }^{7}$

Reactive oxygen species (ROS) and reactive nitrogen species (RNS) generated by xenobiotics, such as toxicants and drugs, play crucial role in the initiation, and progression of nephrotoxicity and renal injuries. ${ }^{8}$

Antioxidant agents can ameliorate these effects in the kidney through modification of the oxidant-antioxidant balances. $^{9}$

An antioxidant is defined as any substance which when present at low concentrations delays or prevents oxidations of cell contents like lipids, proteins, carbohydrates and DNA. Superoxide dismutase (SOD), Catalase (CAT) and Glutathione reductase are the first line endogenous antioxidants in the human body. ${ }^{10}$

Antioxidamt minerals include Selenium (Se), Magnesium $(\mathrm{Mg})$, Copper $(\mathrm{Cu})$ and Zinc $(\mathrm{Zn}) .{ }^{11}$ Oxidative stress results when the balance between ROS and antioxidant defense is lost. ${ }^{12}$ Plants have efficient complex enzymatic and non-enzymatic antioxidant defense systems to avoid the toxic effects of free radicals. Enzymatic systems include SOD, catalase (CAT), glutathione peroxidase $(\mathrm{GPx})$, and glutathione reductase (GR), while nonenzymatic systems consist of low molecular weight antioxidants (ascorbic acid, glutathione, proline, carotenoids, phenolic acids, flavonoids, etc.) and high molecular weight secondary metabolites such as tannins. Commonly used plants with antioxidant properties are Curcuma Domestica (Turmeric), Ocimim Sanctum (Tulsi), Withania Somnifera (Ashwagandha), Embeleca Officinalis (Amla) etc. ${ }^{13}$

Malondialdehyde is a highly reactive compound that is not typically observed in pure form. It results from lipid peroxidation of polyunsaturated fatty acids. The degree of lipid peroxidation can be estimated by the amount of malondialdehyde in tissues. ${ }^{14}$

Free oxygen radicals can induce lipid peroxidation in cells, and malondialdehyde (MDA) is formed during oxidative degeneration and accepted an indicator of lipid peroxidation.

Superoxide dismutase (SOD) is an antioxidant enzyme. It protects cells against oxygen free radical damage by providing reducing equivalents for several enzymes. Aminoglycoside antibiotics are known to facilitate the generation of oxygen free species both in vivo and in vitro which plays an important role in aminoglycoside induced nephrotoxicity. ${ }^{15}$

The World Health Organization found that $80 \%$ of the world's population depends on medicinal plants for their healthcare needs, and more than $30 \%$ of the pharmaceutical preparations are based on plants.

Hemidesmus indicus Linn. $\mathrm{R} . \mathrm{Br}$ is a twining shrub, belonging to the family Asclepiadaceae. Roots of this taxon are being used in folk medicine as well as in ayurvedic and unani preparations. They are prescribed against the diseases of blood, inflammation, diarrhea, respiratory disorders, skin diseases, syphilis, fever, bronchitis, asthma, eye diseases; epileptic fits in children, kidney and urinary disorders, loss of appetite, burning sensation and rheumatism. ${ }^{16-18}$

Withania somnifera, also known as ashwagandha /Winter cherry/ Indian ginseng is widely used in Ayurvedic medicine. It belongs to the family of Solanaceae. The leaves, fruits, seeds, shoots and roots of this plant have all been used traditionally. The roots of Withania somnifera contain 35 chemical constituents. Most of the biological actions have been attributed to the active ingredients $i$ :e Withaferin A and withanolides. The roots of this plant are known to promote health and longevity by augmenting defense against some diseases, arresting the aging process, revitalizing the body in debilitated condition, increasing the capability of an individual to resist adverse 
environment factors. No side effects have been reported so far with this plant. ${ }^{19,20}$

Due to the serious adverse effects of Aminoglycosides on kidney, the present study was designed to compare the effect of Withania somnifera and Hemidesmus Indicus on gentamicin induced nephrotoxicity in experimental animals.

Aim of the study was to compare the effect of Hemidismus Indicus and Withania Somnifeara on Gentamicin induced nephrotoxicity in albino rats.

\section{Objectives}

- To induce nephrotoxicity with Gentamicin.

- To evaluate the effect Hemidesmus indicus on gentamicin induced nephrotoxicity.

- To evaluate the effect of Withania somnifera on gentamicin induced nephrotoxicity.

- To compare the effect of Hemidesmus indicus and Withania somnifera on gentamicin induced nephrotoxicity.

Duration of the study was 1 month. There were 32 albino rats used in the study. It was an an experimental study. The study was carried out in Animal House, Department of Pharmacology, JNMC, Wardha.

\section{METHODS}

Wistar albino rats of either sex weighing 180-250gm were utilized for the study. Experiment was performed after due permission from the Institutional Animal Ethics Committee (IAEC).

Table 1: Experimental animals were grouped.

\begin{tabular}{|lll|}
\hline Group & Treatment given & Duration \\
\hline I & $\begin{array}{l}\text { Normal saline } 10 \mathrm{ml} / \mathrm{kg} \\
\text { intraperitoneally (IP) daily }\end{array}$ & 10 days \\
\hline II & $\begin{array}{l}\text { Gentamicin } 80 \mathrm{mg} / \mathrm{kg} \text { body } \\
\text { weight intraperitoneally ((IP) } \\
\text { daily }\end{array}$ & 10 days \\
\hline \multicolumn{4}{|c|}{ III } & $\begin{array}{l}\text { Hemidesmus Indicus } 7 \mathrm{~g} / \mathrm{kg} / \mathrm{day} \\
\text { PO along with Inj. Gentamicin } \\
\text { 80mg/kg body weight } \\
\text { intraperitoneally (IP) daily }\end{array}$ & \\
\hline & $\begin{array}{l}\text { Withania Somnifera } \\
\text { 500mg/kg/day PO along with } \\
\text { IV }\end{array}$ & $\begin{array}{l}\text { Gentamicin } 80 \mathrm{mg} / \mathrm{kg} \text { body } \\
\text { weight daily intraperitoneally } \\
\text { (IP) daily }\end{array}$ \\
\hline
\end{tabular}

All rats were kept under observation for 1 week prior to the experiment to permit the animals to adjust to the environment. Blood samples were collected through retrorbital puncture a day before starting the study and on the $10^{\text {th }}$ day. These samples were centrifuged for 10 minutes at 3000rpm and sera were obtained. Samples were analyzed for blood urea, serum creatinine, MDA and SOD levels. All specimens of sera were stored at $-20^{0}$ Celsius until use. Results were measured using a spectrophotometer.

\section{RESULTS}

Statistical analysis was done by using descriptive and inferential statistics using one way ANOVA and Multiple comparison Tukey test and software used in the analysis was SPSS17.0 version and $p<0.05$ is considered as level of significance.

Table 2: Comparison of blood urea in four groups.

\begin{tabular}{|lllllll|}
\hline Group & N & Mean & $\begin{array}{l}\text { Std. } \\
\text { deviation }\end{array}$ & $\begin{array}{l}\text { Std. } \\
\text { error }\end{array}$ & $\begin{array}{l}\text { Mini- } \\
\text { mum }\end{array}$ & $\begin{array}{l}\text { Maxi- } \\
\text { mum }\end{array}$ \\
\hline Group I & 8 & 18.80 & 1.62 & 0.57 & 16.13 & 20.83 \\
\hline $\begin{array}{l}\text { Group } \\
\text { II }\end{array}$ & 8 & 77.13 & 3.62 & 1.28 & 70.76 & 81.13 \\
\hline $\begin{array}{l}\text { Group } \\
\text { III }\end{array}$ & 8 & 40.30 & 3.78 & 1.33 & 35.12 & 46.34 \\
\hline $\begin{array}{l}\text { Group } \\
\text { IV }\end{array}$ & 8 & 33.69 & 2.43 & 0.85 & 30.45 & 36.45 \\
\hline
\end{tabular}

Mean blood urea level in group I was $18.80 \pm 1.62$, in group II it was 77.13 \pm 3.62 , in group III it was $40.30 \pm 3.78$ and in group IV it was 33.69 \pm 2.43 . By using one way ANOVA statistically significant variation was found in mean urea level among four groups $(\mathrm{F}=546.47$, $\mathrm{p}$-value=0.0001). On comparing blood urea level in four groups using Multiple Comparisons: Tukey Test statistically significant variation was found in mean urea level among four groups $(\mathrm{p}<0.05)$.

Table 3: Comparison of serum creatinine in four groups.

\begin{tabular}{|lllllll|}
\hline Group & $\mathbf{N}$ & Mean & $\begin{array}{l}\text { Std. } \\
\text { deviation }\end{array}$ & $\begin{array}{l}\text { Std. } \\
\text { error }\end{array}$ & $\begin{array}{l}\text { Mini- } \\
\text { mum }\end{array}$ & $\begin{array}{l}\text { Maxi- } \\
\text { mum }\end{array}$ \\
\hline Group I & 8 & 0.84 & 0.08 & 0.03 & 0.72 & 0.94 \\
\hline $\begin{array}{l}\text { Group } \\
\text { II }\end{array}$ & 8 & 3.00 & 0.56 & 0.19 & 2.30 & 3.80 \\
\hline $\begin{array}{l}\text { Group } \\
\text { III }\end{array}$ & 8 & 1.62 & 0.23 & 0.08 & 1.30 & 2.00 \\
\hline $\begin{array}{l}\text { Group } \\
\text { IV }\end{array}$ & 8 & 1.57 & 0.23 & 0.08 & 1.20 & 1.90 \\
\hline
\end{tabular}

Table 4: Comparison of SOD in four groups.

\begin{tabular}{|lllllll|}
\hline Group & $\mathbf{N}$ & Mean & $\begin{array}{l}\text { Std. } \\
\text { deviation }\end{array}$ & $\begin{array}{l}\text { Std. } \\
\text { error }\end{array}$ & $\begin{array}{l}\text { Mini- } \\
\text { mum }\end{array}$ & $\begin{array}{l}\text { Maxi- } \\
\text { mum }\end{array}$ \\
\hline Group I & 8 & 1.74 & 0.12 & 0.04 & 1.57 & 1.95 \\
\hline $\begin{array}{l}\text { Group } \\
\text { II }\end{array}$ & 8 & 0.05 & 0.01 & 0.006 & 0.03 & 0.08 \\
\hline $\begin{array}{l}\text { Group } \\
\text { III }\end{array}$ & 8 & 0.75 & 0.11 & 0.040 & 0.56 & 0.91 \\
\hline $\begin{array}{l}\text { Group } \\
\text { IV }\end{array}$ & 8 & 0.82 & 0.07 & 0.025 & 0.74 & 0.93 \\
\hline
\end{tabular}


Mean serum Creatinine level in group I was $0.84 \pm 0.08$, in group II it was $3.00 \pm 0.56$, in group III it was $1.62 \pm 0.23$ and in group IV it was $1.57 \pm 0.23$. By using one way ANOVA statistically significant variation was found in mean creatinine level among four groups $(\mathrm{F}=60.07$, $\mathrm{p}$ value $=0.0001$ ). On comparing serum Creatinine level in four groups using Multiple Comparisons: Tukey Test statistically significant variation was found in mean creatinine level among four groups $(\mathrm{p}<0.05)$.

Mean SOD level in group I was $1.74 \pm 0.05$, in group II it was $0.05 \pm 0.01$, in group III it was $0.75 \pm 0.11$ and in group IV it was $0.82 \pm 0.07$. By using one way ANOVA statistically significant variation was found in mean SOD level among four groups $(\mathrm{F}=442.71$, $\mathrm{p}$-value=0.0001). On comparing SOD level in four groups using Multiple Comparisons: Tukey Test statistically significant variation was found in mean SOD level among four groups $(\mathrm{p}<0.05)$.

Table 5: Comparison of MDA in four groups.

\begin{tabular}{|lllllll|}
\hline Group & N & Mean & $\begin{array}{l}\text { Std. } \\
\text { deviation }\end{array}$ & $\begin{array}{l}\text { Std. } \\
\text { error }\end{array}$ & $\begin{array}{l}\text { Mini- } \\
\text { mum }\end{array}$ & $\begin{array}{l}\text { Maxi- } \\
\text { mum }\end{array}$ \\
\hline Group I & 8 & 1.23 & 0.08 & 0.02 & 1.15 & 1.38 \\
\hline $\begin{array}{l}\text { Group } \\
\text { II }\end{array}$ & 8 & 2.79 & 0.36 & 0.12 & 2.13 & 3.16 \\
\hline $\begin{array}{l}\text { Group } \\
\text { III }\end{array}$ & 8 & 1.71 & 0.15 & 0.05 & 1.51 & 1.93 \\
\hline $\begin{array}{l}\text { Group } \\
\text { IV }\end{array}$ & 8 & 1.61 & 0.12 & 0.04 & 1.45 & 1.81 \\
\hline
\end{tabular}

Mean MDA level in group I was $1.23 \pm 0.08$, in group II it was $2.79 \pm 0.36$, in group III it was $1.71 \pm 0.15$ and in group IV it was $1.61 \pm 0.12$. By using one way ANOVA statistically significant variation was found in mean MDA level among four groups $(\mathrm{F}=79.74$, $\mathrm{p}$-value=0.0001). On comparing MDA level in four groups using Multiple Comparisons: Tukey Test statistically significant variation was found in mean MDA level among four groups $(\mathrm{p}<0.05)$.

\section{DISCUSSION}

This study groups included albino rats with normal renal function. They were given Gentamicin by intraperitoneal route for 10 days. Significant nephrotoxicity was seen with Gentamicin in comparison with the control group. Study parameters of Blood urea, serum creatinine and MDA levels were significantly higher in gentamicin treated group. This group also showed a marked reduction in SOD levels. Study groups III and IV were concurrently administered Hemidesmus Indicus at a dose of $7 \mathrm{~g} / \mathrm{kg} /$ day PO and Withania Somnifera at a dose of $500 \mathrm{mg} / \mathrm{kg} /$ day PO for 10 days. Renal function was monitored on Day 1 and then on Day 10.

Our results concluded that Hemidesmus Indicus and Withania Somnifera had a significant nephroprotective effect. This was evident by a reduction in Blood Urea,
Serum Creatinine. An increase in SOD level and decrease in MDA level in comparison with the control group showed significant reduction in oxidative stress.

These results confirmed that Gentamicin produced nephrotoxicity as previously reported by authors. ${ }^{21}$ These changes reflected the severity of renal insufficiency which occurred in association with the sudden fall in glomerular filtration rate because of the majority of administrated GM enters specifically the proximal tubular epithelial cells, binds to anionic phospholipids in the target cells inducing abnormalities in the function an d metabolism of multiple intracellular membranes and organelles then developed injury in the proximal tubular epithelial cells of kidney that caused acute renal failure. ${ }^{22}$

Russo A et al reported that phytochemicals present in Withania somnifera are responsible in overcoming oxidative stress. ${ }^{23}$ This result are also in accordance with these earlier reports.

\section{CONCLUSION}

This study concludes that Hemidesmus indicus at a dose of $7 \mathrm{~g} / \mathrm{kg} /$ day and Withania somnifera at a dose of $500 \mathrm{mg} / \mathrm{kg}$ showed nephroprotective effect in Gentamicin induced nephrotoxicity. We also concluded that Withania Sominfera is more nephroprotective than Hemidesmus indicus.

\section{Funding: No funding sources Conflict of interest: None declared \\ Ethical approval: The study was approved by the Institutional Animal Ethics Committee}

\section{REFERENCES}

1. Definition of Aminoglycoside: Available at: www.merriam-webster.com/medical/aminoglycoside.

2. Mingeot-Leclercq MP, Glupczynski Y, Tulkens PM. Aminoglycosides: activity and resistance. Antimicrob Agents Chemother. 1999;43:727-37.

3. Nagai J. Molecular mechanisms underlying renal accumulation of aminoglycoside antibiotics and mechanism-based approach for developing nonnephrotoxic aminoglycoside therapy. Yakugaku Zasshi. 2006;126(5):327-35.

4. Pfaller W. Structure function correlation on rat kidney. Quantitative correlation of structure and function in the normal and injured rat kidney. Adv Anat Embryol Cell Biol. 1982;70:1-106.

5. Maliakel DM, Kagiya TV, Nair CK. Prevention of Cisplatin-Induced Nephrotoxicity by Glucoside of Ascorbic acid and $\alpha$-tocopherol. Experimental and Toxicologic Pathology. 2008;60:521-7.

6. Hou SH, Bushinsky DA, Wish JB, Cohen JJ, Harrington JT: Am J Med. 1983;74:243-8.

7. Paterson DL, Robson JMB, Wagener MM. Risk factors for toxicity in elderly patients given 
aminoglycosides once daily. J Gen Intern Med. 1998;13:735-9.

8. Uehara T, Miyoshi T, Tsuchiya N, Masuno K, Okada $\mathrm{M}$, Inoue $\mathrm{S}$, et al. Comparative analysis of gene expression between renal cortex and papilla in nedaplatin-induced nephrotoxicity in rats. Human \& experimental toxicology. 2007 Oct;26(10):767-80.

9. Lin HM, Yen FL, Ng LT, Lin CC. Protective effects of Ligustrum lucidum fruit extract on acute butylated hydroxy-toluene induced oxidative stress in rats. J Ethnopharmacol. 2007;111:129-36.

10. Irshad M, Chaudhari PS. Oxidant and antioxidant system: role and significance in human body. Indian $\mathrm{J}$ Exp Biol. 2002;40:1233-9.

11. Duthie GG, Brown KM. Reducing the Risk of Cardiovascular Disease, In: Functional Foods, ed. Goldberg, I. Chapman and Hall: New York; Chapter 2, 1994:19-38.

12. Chand S, Dave R. In vitro models for antioxidant activity evaluation and some medicinal plants possessing antioxidant properties: an overview. Afr J Microbiol Res. 2009;3:981-96.

13. Krishnaiah D, Sarbatly R, Nithyanandam R. A review of the antioxidant potential of medicinal plant species. Food Bioprod Process. 2011;89:217-33.

14. Del Rio D, Stewart AJ, Pellegrini N. A review of recent studies on malondialdehyde as toxic molecule and biological marker of oxidative stress. Nutr Metab Cardiovasc Dis. 2005;15(4):316-28.

15. Neilsen F, Mikkelsen BB, Neilsen JB, Andersen HR, Grandjean P. Plasma malondialdehyde as biomarker for oxidative stress: reference interval and effects of life-style factors. Clin Chemist. 1997;47:1209-14.

16. Mary NK, Achuthan CR, Babu BH, Padikkala J. In vitro antioxidant and antithrombotic activity of
Hemidesmus indicus (L) R.Br. J Ethnopharmacol. 2003;87:187-91.

17. Vaidya K, Kulkarni PH. A study of an ayurvedic formula viz-Jivak. Deerghaya International 1991;7:20.

18. Nadkarni AN. Indian material medica. Edn1, Popular Book Depot, Bombay, India. 1989;1:619.

19. Mishra L C, Singh BB, Dagenais S. Scientific basis for the therapeutic use of with aniasomnifera (Ashwagandha): a review. Altern Med Rev. 2000;5:334-46.

20. Bone K. Clinical applications of Ayurvedic and Chinese herbs. Monographs for the Western herbal practioner. Aust Phytotherapy Press. 1996:137-41.

21. Heibashy MIA, El-Nahla AM, Ibrahim AI, Saleh Sh YA. Comparative study between dimethyl sulfoxide (DMSO), all opurinol and urate oxidase administration in nephrotoxic rats induced with gentamicin. $43^{\text {rd }}$ Annual Veterinary Medical Symposium, College of Veterinary Medicine Nursing and Allied Health, Tuskegee University, Alabama, USA; 2009.

22. Swan SK. Aminoglycoside nephrotoxicity: review. Seminars in nephrology. 1997;17(1):27-33.

23. Russo A, Izzo AA, Cardile V, Borrelli F, Vanella A:Indian medicinal plants asantiradicals and DNA cleavage protectors. Phytomedicine. 2001;8:125-32.

Cite this article as: Padhye MR, Jogdand SD, Bhattacharjee J. Evaluation and comparison of nephroprotective effect of Hemidesmus indicus Linn. and withania somnifera Linn. on gentamicin induced nephrotoxicity in Albino rats. Int J Basic Clin Pharmacol 2018;7:691-5. 